\title{
Dookoła świata z Orsonem Wellesem
}

\author{
Matgorzata KOZUBEK
}

\section{Pora na nowe otwarcie}

Esej Mirosława Przylipiaka, otwierający tom zatytułowany Orson Welles. Twórczość - Recepcja-Dziedzictwo, który jest pokłosiem sesji naukowej zainspirowanej stuleciem urodzin Wellesa przypadającym w 2015 r., kończy się słowami: Czas na nowe otwarcie ${ }^{1}$. Gdański filmoznawca, wnikliwie analizując obecność jednego z najsłynniejszych reżyserów amerykańskich na gruncie polskiego piśmiennictwa filmowego, zwraca między innymi uwagę na stosunkowo niewielkie zainteresowanie stylem Wellesa po jego spektakularnym pełnometrażowym debiucie, całkowity brak opisów aspektów produkcyjnych i dystrybucyjnych jego twórczości oraz często powtarzane stereotypy na jego temat ${ }^{2}$. Warto zauważyć, że do niedawna nie tylko w polskich opracowaniach istniała tendencja do pisania o Wellesie głównie w kontekście jego arcydzieł i barwnego życia osobistego, zakładając, że wszystkie jego mniejsze produkcje, w tym liczne realizacje telewizyjne, były dyktowane jedynie potrzebą zdobycia pieniędzy na kolejne poważne dzieło ${ }^{3}$. Owe braki i uproszczenia wynikały w dużej mierze z trudnego dostępu do niepublikowanych materiałów archiwalnych, które rzucają nowe i - jak się wydaje - bardziej obiektywne światło na życie twórcy Obywatela Kane'a. Clinton Heylin, wypowiadając się o mitotwórcach ${ }^{4}$, czyli poprzednich biografach Wellesa, nie przebiera w słowach: Dość powiedzieć, że wiele jeszcze trzeba zrobić, aby rozwiać miazmaty, którymi spowili reżysera i jego dzieło ${ }^{5}$. Sprawy nie ułatwia(ł) fakt, że niezwykle bogate archiwalia nie tylko są rozproszone po całym świecie, ale jeszcze do niedawna znajdowały się głównie w zbiorach prywatnych i dopiero od pewnego czasu są stopniowo przekazywane do bibliotek oraz muzeów (lub są przez te instytucje kupowane), dając szansę miłośnikom i badaczom Orsona Wellesa z całego świata na zapoznanie się z nimi ${ }^{6}$.

Do „nowego otwarcia” zachęcają nie tylko uchylone drzwi archiwów, etapowa digitalizacja materiałów, które się w nich znajdują i dostępność niektórych z nich w Internecie ${ }^{7}$, ale i wydana w 2015 r. przez British Film Institute pełna telewizyjna seria Around the World with Orson Welles (1955), która była brakującym ogniwem w opisach twórczości reżysera. Po licznych perturbacjach została również ukończona ostatnia produkcja Wellesa, Druga strona wiatru (The Other Side of the Wind, 2018), która trzydzieści trzy lata po śmierci twórcy Obywatela Kane'a domyka jego filmografię ${ }^{8}$. Obraz ten jest dosłownym (również pod względem tematyki) powrotem Wellesa do Hollywood po wieloletniej europejskiej imigracji, która miała dać mu więcej swobody w realizacji filmów. I mimo że Europa nie do końca 
spełniła pokładane w niej nadzieje na niezależność artystyczną, podobnie jak obie Ameryki, stała się dla reżysera inspirującym domem.

Wyruszmy zatem w podróż szlakiem twórcy Obywatela Kane'a, znaczoną tym razem nie legendami i zasłyszanymi anegdotami, które powtarzane i ubarwiane w różnych opracowaniach stały się wręcz karykaturalne, ale dokumentalnymi esejami filmowymi Around the World with Orson Welles, jego - jak byśmy to dziś nazwali - wideoblogami zatytułowanymi Orson Welles'Sketchbooks oraz z konkretnymi materiałami archiwalnymi w ręku. Wędrówkę tę moglibyśmy zacząć niemal w dowolnym miejscu na Ziemi, zwłaszcza kiedy przypomnimy sobie, że Welles zaczął swoje wojaże bardzo wcześnie - w każdej jego biografii jest przywoływana informacja o podróży dookoła świata, którą odbył z ojcem, kiedy miał zaledwie 12 lat: Odziedziczyłem po ojcu miłość do podróży, włóczegi, która zakorzeniła się we mnie głęboko ${ }^{9}$.

Gdzie zatem zacząć tę drogę? W Stanach Zjednoczonych, w których się urodził i rozpoczął karierę? W Europie, gdzie spędził znaczną część życia? W Afryce, która go fascynowała? W Ameryce Południowej, którą uwielbiał tak bardzo, że okres w niej spędzony wspominał jako najwspanialszy karnawat w swoim życiu ${ }^{10}$ ? Lubił powtarzać, że został poczęty w Rio (zawsze mówił „Rio”, a nie „Rio de Janeiro”) podczas jednej z podróży swoich rodziców ${ }^{11}$. Okres z realizacji nieukończonego filmu It’s All True (1941-1942), do którego zdjęcia były kręcone w Argentynie, Brazylii i Meksyku, według wielu świadectw i zdjęć dostępnych w archiwach, był jednym z najbardziej beztroskich i szczęśliwych w życiu Orsona Wellesa. Nie wiedział jeszcze wtedy, jak bezwzględnie wytwórnia RKO rozprawi się w montażowni ze Wspaniałością Ambersonów (1942), że reżyserię Podróży do krainy strachu (Journey Into Fear, 1943) przekaże w zasadzie Normanowi Fosterowi, a jego panamerykańska odyseja ${ }^{12}$ nie zakończy się sukcesem. Według ówczesnego producenta RKO, George'a J. Schaefera, z którym notabene Welles się przyjaźnił, reżyser sam był sobie winien - prowadził nonszalanckie i rozrzutne życie, zapominał o spotkaniach ze sponsorami, nie odbierał telefonów z wytwórni, a wyjazdy do Brazylii traktował jak przyjemne wakacje, nie interesując się przesadnie tym, co się dzieje z postprodukcją jego dwóch innych filmów w Stanach Zjednoczonych. Choć rzeczywiście zachowały się liczne telegramy do Wellesa wysyłane przez Schaefera, w których ten pisał o potwornie kłopotliwej sytuacji ${ }^{13}$ i podkreślał, że jest osobiście odpowiedzialny za cała te poludniowoamerykańska eskapadę ${ }^{14}$, to jednak warto mieć na uwadze, że osobisty asystent reżysera, Richard Alan Wilson, wysyłał regularnie nie tylko szczegółowe sprawozdania z produkcji, ale i precyzyjne wskazówki Wellesa dotyczące montażu Ambersonów ${ }^{15}$. Po latach Welles przyznał gorzko, że It's All True jest jedną z jego największych porażek: Kosztowało mnie to naprawdę wiele; wiele innych filmów, których nigdy nie zrobiłem $i$ wiele lat, podczas których nie mogłem $w$ ogóle pracować ${ }^{16}$.

Niezależnie jednak od legendarnych nieporozumień z hollywoodzkimi producentami ${ }^{17}$, wielokrotnie zaprzepaszczonych szans i straconych nadziei, warto wiedzieć, że Welles do końca życia nie tylko starał się spełnić swoje największe marzenie o tworzeniu bezkompromisowego kina (nawet jeśli musiał to czasami robić za własne pieniądze), ale bez ustanku szukał inspiracji do swojej twórczości podczas niezliczonych podróży. W Wellesowskich archiwach szczególne miejsce zajmują rysunki. Z przeglądu zawartości folderów znajdujących się w archiwach 
można wywnioskować, że Welles kompulsywnie rysował - nie tylko na białym papierze, ale i na scenariuszach, kartkach pocztowych, serwetkach znalezionych w barach. Portretował ludzi, których spotykał, pejzaże, zwykłe budynki i okazałe zamki. Niektóre z tych prac są naprędce sporządzonymi szkicami, niektóre wyglądają jak gotowe storyboardy. Wśród jego rysunków sporo jest projektów kostiumów inspirowanych lokalnymi ubiorami, które znajdą swoje piękne rozwinięcie w jego sztukach teatralnych i filmach. Niezwykle interesujące są też listy z podróży i telegramy wysyłane z rozmaitych miejsc i sugerujące, że właśnie odkrył nowe eldorado albo przynajmniej lokację, w której nakręci swój kolejny film.

Wobec konieczności dokonania wyboru nie zatrzymamy się zbyt długo w miejscach najbardziej kojarzonych z Wellesem, jak chociażby w Hiszpanii ${ }^{18}$ (znana jest jego fascynacja corridą czy postacią Don Kichota ${ }^{19}$ ) i pominiemy regiony, w których realizował It's All True oraz Włochy i wybrzeże dalmatyńskie o ich związkach z życiem i twórczością Wellesa ukazały się bowiem niedawno wyczerpujące monografie ${ }^{20}$. Innym kluczem w niniejszym, subiektywnym przeglądzie będzie chronologiczny układ tych najwcześniejszych podróży Wellesa, które niewątpliwie go ukształtowały i związany z nimi wątek utraconego raju - jednego z najważniejszych tematów w twórczości, począwszy od Obywatela Kane'a przez Wspaniałość Ambersonów, a na Drugiej stronie wiatru i kilkudziesięciu nigdy niezrealizowanych projektach skończywszy, jak chociażby bardzo mało znanym, a szczegółowo zaplanowanym pomyśle, by przenieść na ekran Małego Księcia ${ }^{21}$, który bardzo konsekwentnie wpisuje się w koncepcję Wellesa przypominającą, że żaden raj nie może trwać wiecznie ${ }^{22}$.

\section{Kenosha - pierwszy raj utracony}

Kiedy dziś spaceruje się po Kenoshy, niewielkim mieście w stanie Wisconsin, znajdującym się niecałe sto kilometrów na północ od Chicago, można odnieść wrażenie, że jest to miejsce wymarłe. Przypomina opustoszałe studio w Hollywood. Przechadzka po pustych uliczkach rodzinnego miasta twórcy Obywatela Kane'a nasuwa skojarzenia ze smutną wizją Ameryki z filmów Wernera Herzoga. W jednym z najpopularniejszych miejsc - osobliwej knajpce Mike's Donuts\&Chicken, która specjalizuje się w pieczonych w całości kurczakach i wielkich lukrowanych pączkach - nikt nie słyszał o tym, że urodził się tutaj słynny reżyser filmowy; miejscowi zachęcają raczej do odwiedzenia muzeum dinozaurów. Dom, w którym przyszedł na świat Welles, jak wynika z rozmowy z jego aktualnymi właścicielami, nie jest zbyt często odwiedzany, choć decydując się na kupno posiadłości przy Siódmej Alei pod numerem 6116 nieco obawiali się oni natrętnych turystów. Tymczasem tylko z rzadka pojawia się tam jakiś fan, żeby zrobić sobie zdjęcie przy skromnej tablicy pamiątkowej umieszczonej przed domem, na której oprócz informacji o dacie urodzenia i śmierci artysty jest napisane jedynie: Orson Welles. Aktor i reżyser. $\mathrm{W}$ domu nie mieści się żadne muzeum, nie pozostało $\mathrm{W}$ nim również nic, co należało do rodziny Wellesów.

Śladów związanych z jego życiem należy szukać gdzie indziej: w archiwach, w których znajdują się rysunki przedstawiające Kenoshę widzianą oczami Wellesa, w pastelowych barwach, z malowniczą latarnią nad brzegiem jeziora Michigan, a także w samych filmach, które niejednokrotnie można czytać w kluczu autobio- 
graficznym. Welles powtarzał, że lubił wracać do czasów swego dzieciństwa. Pamiętamy, że pięcioletni Charlie Kane, wyrwany z bajkowego, śnieżnego (nieistniejącego w rzeczywistości) miasteczka New Salem w Colorado, wyjeżdża z bankierem Thatcherem „do dużego miasta”. Tym dużym miastem w przypadku pięcioletniego Orsona było Chicago, do którego wyjechał z matką w 1920 r. Choć życie w Kenoshy było przyjemne, nie mogło zaoferować takich możliwości i atrakcji jak Chicago położone na tym samym brzegu Wielkiego Jeziora. W mieście tym, będącym centrum kulturalnym Środkowego Zachodu Stanów Zjednoczonych, matka wspólnie z przyjacielem rodziny Mauricem Bernsteinem, którego Welles nazywał Dadda $^{23}$, zabierała syna na koncerty muzyczne i przedstawienia teatralne.

Miasto pierwszych drapaczy chmur musiało skierować wzrok przyszłego reżysera w górę. I być może właśnie w tym miejscu można się doszukiwać pierwszych inspiracji dla powszechnie znanych Wellesowskich rozwiązań wizualnych; filmowanie z żabiej perspektywy stało się wręcz znakiem rozpoznawczym jego filmów. Często też odwiedzał Art Institute, co wiemy z zachowanych zdjęć Wellesa z posągowym lwem, znajdującym się przed słynnym muzeum. Kiedy dziś zwiedza się tę galerię, odnosi się nieodparte wrażenie, że jej oszklone sufity musiały mocno utkwić mu w pamięci - najpierw chętnie je szkicował, a później stosował w filmach. Najwyraźniej widać to bodaj w Obywatelu Kanie w sekwencji rozmowy z Lelandem po przegranych wyborach i w kilku scenach Procesu (Le Procès, 1962), szczególnie w tej, w której Józef K. z obrazami Titorellego w ręku przedziera się przez kręte korytarze sądu wypełnione po sufit regałami.

Łatwo jest zrozumieć powód wyjazdu Wellesa z małego, sennego miasteczka. Nie należy w tym miejscu powtarzać frazesów w stylu: „osobowość Orsona Wellesa rozsadzała Hollywood, a co dopiero małą Kenoshę!” - bo legendy o tym, że pierwsze wypowiedziane przez niego słowa brzmiały: Jestem geniuszem! a jako kilkuletnie dziecko czytał rozprawy filozoficzne o greckim teatrze, są mocno przesadzone ${ }^{24}$. Przez lata Welles wielokrotnie cierpliwie odpowiadał dziennikarzom z całego świata na pytanie o miejsce urodzenia, literując nazwę mało znanego miasta. Jak pisze Patrick McGilligan, autor książki Young Orson - wyczerpującej monografii poświęconej młodości Wellesa - reżyser podkreślał, że jest dumny ze swoich korzeni ${ }^{25}$. Można się jednak domyślać, że nie chodzi jedynie o miejsce, ale przede wszystkim o postać matki, która odegrała dużą rolę w edukacji i rozwijaniu wrażliwości artystycznej syna, a która umarła, kiedy miał zaledwie osiem lat. Szybka utrata dzieciństwa nie była doświadczeniem Williama Randolpha Hearsta, będącego prototypową postacią Charlesa Fostera Kane'a, lecz dotknęła reżysera, odciskając piętno na jego twórczości.

\section{Grand Detour - raj, który spłonąl}

Postać Richarda Heada Wellesa, bon vivanta, wynalazcy i obieżyświata, zasługiwałyby na osobną uwagę. W tym szkicu należy się odnieść w pierwszej kolejności do kilkumiesięcznej podróży, w którą wyruszył z synem w 1927 r. Wprawdzie dwunastoletni Welles uczył się wtedy (1926-1931) w Todd School For Boys w Woodstock ${ }^{26}$, ale ojciec uznał, że chłopak więcej nauczy się, podróżując po świecie, i może zawiesić na jakiś czas instytucjonalną edukację, do której sam Welles i tak nigdy nie był przekonany. Zwłaszcza z perspektywy czasu należy 
uznać, że była to trafna decyzja, ponieważ krótko po tej wspólnej wycieczce ojciec reżysera zmarł. Zwiedzili razem Londyn, Paryż, Singapur, Jamajkę (...) Od czasu do czasu ojciec wymyślat jakiś wynalazek (...) sprzedawał go, po czym pieniądze przeznaczał na kolejna podróż ${ }^{27}$.

Twórca Obywatela Kane'a często pytany, jakie miejsca z wyprawy z dzieciństwa najlepiej zapamiętał i które miasta wywarły na nim największe wrażenie, odpowiadał, że Budapeszt i Pekin ${ }^{28}$. Warto w tym miejscu dodać, że Orson Welles ubarwiał opowieści na temat tych najwcześniejszych podróży. Jeden z jego biografów, David Thomson, przywołuje na przykład wywiad z 1967 r., w którym Welles opowiadał, jak to w połowie lat 20. XX w. podczas jednej z pieszych wędrówek pił piwo w Tyrolu z Adolfem Hitlerem, choć wtedy jeszcze nie miał pojęcia, kim był ten mały mężczyzna zieciekawa osobowością ${ }^{29}$.

Można jednak zrozumieć powody, dla których reżyser często droczył się z dziennikarzami i dowcipkował na temat tych pierwszych mitycznych podróży. Za szarżą i niestworzonymi historiami krył się dramat i kolejny utracony raj, o czym opowiedział Peterowi Bogdanovichowi w wywiadzie-rzece, który ukazał się już po śmierci Wellesa ${ }^{30}$. Rajem tym był wiejski hotel „Sheffield”, który ojciec reżysera kupił w 1924 r. w Grand Detour, niewielkiej miejscowości w stanie Illinois, położonej na wysokości Chicago, oddalonej od tej metropolii około 160 kilometrów.

Przez kilka lat Welles spędzał tam kilka letnio-jesiennych miesięcy w roku, miał tam nawet małą chłopięcą pracownię, w której rysował. Na zachowanych zdjęciach drewniany pensjonat przypomina chatkę ze słynnej śnieżnej kuli Kane'a. Reżyser wyznał, że miejsce to było całkowicie odrealnione, jak z lat siedemdziesiątych XIX w. - anachroniczne, staromodne, pozbawione elektryczności ${ }^{31}$, a jego ojciec nie zrobił nic, by je zmodernizować. Welles z nostalgią wspominał wiejski sklep, nad którym znajdowała się mała sala balowa ze starym parkietem: Podkradałem się tam $w$ nocy $i$ tańczyłem $w$ świetle księżyca z kurzem wznoszacym się z podtogi... Grand Detour byt jednym z tych utraconych światów, jednym z tych Edenów, z których nas wyrzucono ${ }^{32}$.

Hotel ,Sheffield” został zniszczony w pożarze 14 maja 1928 r., wkrótce po ukończeniu przez Wellesa 13. roku życia. Nigdy już tam nie wrócił, ale próbował odtworzyć raje, o których mówił Bogdanovichowi w swoich filmach. Falstaff (Chimes at Midnight, 1965), który był ulubionym dziełem Wellesa i z którego był najbardziej zadowolony, rozgrywał się częściowo w takim raju - w tawernie „Pod Dzikiem” ${ }^{3}$. Jest to urocze gniazdo rozkoszy (pamiętne sceny z Jeanne Moreau grającą wiecznie roześmianą prostytutkę), w którym Welles - zafascynowany całe życie „,niewinnymi", preindustrialnymi miejscami - sam wszystko zaprojektował ${ }^{34}$. Przykładami odtwarzania utraconych rajów są również wyidealizowane ,śnieżne sceny” z Obywatela Kane'a i Wspaniałości Ambersonów. Booth Tarkington, autor pierwowzoru literackiego tego drugiego filmu, był częstym gościem w Grand Detour i przez wiele lat przyjaźnił się z ojcem Wellesa. Postać grana przez Josepha Cottena jest wzorowana właśnie na nim. Przypomnijmy też, że akcja Ambersonów toczy się w niedużym mieście w Środkowych Stanach, a dom tytułowej rodziny jest tu, jak celnie zauważa Alicja Helman, głównym bohaterem, to dom-świat ${ }^{35}$.

Welles nie ukończył nigdy swojej autobiografii, porzucił jej pisanie zaledwie po dwóch pierwszych rozdziałach, które dotyczyły rodziców, najbardziej czarujacych ludzi, jakich znat ${ }^{36}$. Jednak w grudniu 1982 r., trzy lata przed śmiercią, zre- 
dagował gościnnie świąteczny numer paryskiego magazynu „Vogue” 37 , w którym znalazł się fragment memuaru poświęconego ojcu: To, co mu się najbardziej podobało, to jak sądzę, przeprawy przez morze - dtuga wolność od ziemi, w której czut się coraz bardziej ograniczony. Nie było bardziej przyjaznego miejsca dla mojego ojca niż bar miłego, staromodnego liniowca morskiego... ${ }^{38}$ Po ukończeniu szkoły w Woodstock i bardzo krótkim studiowaniu w Art Institute of Chicago, gdzie uczęszczał na zajęcia Borisa Anisfelda, Welles wsiadł na taki okręt i wyruszył w pierwszą samotną podróż.

\section{Irlandia - raj odnaleziony}

Kiedy wczesnym latem 1931 r. Orson Welles wsiadał w Nowym Jorku na okręt Baltic płynący do Irlandii, w kieszeni miał kilkaset dolarów, które otrzymał w spadku po ojcu. Z jednej strony, sam musiał się troszczyć o własną przyszłość, z drugiej, mógł cieszyć się wolnością. Miał zaledwie 16 lat, ale dzięki swojemu bardzo wysokiemu wzrostowi (metr osiemdziesiąt siedem) wyglądał na dorosłego mężczyznę, więc nikt nie zwracał uwagi na samotnie podróżującego nastolatka. Był już zresztą wprawiony w podróżach, więc nie mógł wyglądać na zagubionego i niepewnego siebie młodzieniaszka.

Daniel Boorstin, dokonując w latach 60. ubiegłego wieku rozróżnienia na podróżnika i turystę, napisał: I tak podróżnik miat coś na myśli; turysta szukat przyjemności. Podróżnik byl aktywny; usilnie wędrowat w poszukiwaniu ludzi, przygód, doświadczenia. Turysta jest pasywny; oczekuje, że interesujące rzeczy same mu się przydarza (...). Oczekuje, że wszystko zostanie z nim i dla niego zrobione. Tak więc zagraniczna podróż przestała być działaniem - doświadczeniem, przedsięwzięciem - a stała się za to towarem ${ }^{39}$.

Mimo że Welles nie miał konkretnych planów na przyszłość, „niczego konkretnego na myśli”, powyższa definicja podróżnika idealnie pasuje do jego pierwszej samotnej wyprawy. Po dwóch dniach podróży z jednej z największych metropolii świata znalazł się w zupełnie innym świecie. W pierwszym liście z wyprawy, wysłanym do Bernsteina, napisał: Przygody, których doświadczałem podczas podróży do takich krajów, jak Japonia czy Chiny, przekraczały moje oczekiwania, ale przez szesnaście lat mojego krótkiego życia nic porównywalnego z Galway i zachodnia Irlandia nie zmieniło tak gwattownie mojego spojrzenia na świat ${ }^{40}$. Był zachwycony miejscem, ale przede wszystkim ludźmi - ich zwyczajami, życzliwością i szczerością. Tygodniami wędrował po górach, spędził trochę czasu z Cyganami, spał pod gołym niebem. Słowem - odnalazł tam wizualnie fascynujący i preindustrialny świat utracony w Grand Detour.

Orson Welles chętnie opowiadał historię o tym, że kupił osiołka o imieniu Sheeog, z którym przeszedł drogę z Galway do Donegal na północy Irlandii ${ }^{41}$. Można by pomyśleć, że to wymyślona przez niego bajka, ale w archiwach znajduje się wiele zdjęć z tej wyprawy, a na nich jest widoczny ów osiołek. Następnie udał się na Wyspy Aran. Właśnie tam powstał Człowiek z Aran Roberta Flaherty’ego (Man of Aran, 1934), notabene pionier dokumentalizmu rozpoczął zdjęcia do filmu w roku pobytu Orsona Wellesa na wyspie. Za niecałą dekadę tych dwóch twórców spotka się przy okazji współpracy przy It's All True, ale tymczasem Welles znalazł się w świecie jego filmów i - jak pisze Simon Callow - zetknął się tam z jeszcze 
bardziej intymna wspólnotą niż ta z Zachodniego Wybrzeża, i z która jeszcze łatwiej się zidentyfikowat ${ }^{42}$.

Ta idylla nie mogła trwać wiecznie; kilkunastoletni Welles musiał zarabiać na życie. W liście do Hortense Hill (żony Rogera Hilla z Todd School) pisał: Życie tutaj osiagnęto prostotę $i$ artyzm przewyższajacy wszystko-jestem pewien, że gdzieś na Morzach Południowych może być jakaś zapomniana kraina, gdzie oczy ludzi sa tak jasne, a serca tak otwarte. Ale nigdzie nie ma s z c zerości tak nadzwyczajnie połaczonej z in tel ig en cja, inteligencja, która wynika z liczacego prawie pięć tysięcy lat zaplecza kulturowego. Będac w petni świadoma tych kilku podkreślonych cudów, możesz się domyślić, że moje wędrówki zaprowadzity mnie do swego rodzaju zaginionego Edenu, bogatego w miłość i niezmierzone piękno... Bardzo trudno mi będzie zostawić mój mały domek nad morzem dla świata tramwajów i skórzanych butów, który kiedyś znałem ${ }^{43}$.

We wrześniu 1931 r. romantycznie nastawiony do życia Welles udał się do Gate Theatre w Dublinie i przedstawił się tam jako znany aktor z Nowego Jorku, mówiąc, że jest tym Wellesem, o którym na pewno czytali ${ }^{44}$.Ten efektowny (i efektywny zarazem) blef jest bardzo dobrze znany kinofilom, ponieważ powtarza się go w popularnych artykułach, zwykle tuż przed informacją (wyolbrzymioną) o ataku paniki wywołanym Wojna światów. Welles do końca życia utrzymywał, że dyrektor dublińskiego teatru Hilton Edwards uwierzył mu, że jest wielką gwiazdą, ale niezależnie od tego, jak było naprawdę, musiał zrobić naprawdę dobre wrażenie, bo od razu zatrudniono go do roli (osiemdziesięcioletniego!) księcia Karola Aleksandra w Żydzie Süssie Liona Feuchtwangera. Nie bez znaczenia było zapewne to, że Welles pokazał swoje rysunki i podczas przygotowywania inscenizacji chętnie korzystano z jego wyobraźni wizualnej. Welles występował w dublińskim teatrze od października $1931 \mathrm{r}$. do stycznia roku następnego.

Pierwszy odcinek z serii Orson Welles'Sketch Book, zatytułowany The Early Days (BBC, 24.04.1955), dotyczy właśnie tego dublińskiego epizodu w karierze reżysera, który filmowany w półzbliżeniu zwraca się wprost do widza. Dzisiaj jego szkicowniki nazwalibyśmy zapewne wideoblogami, a Wellesa pierwszym vlogerem w historii, gdyby nie fakt, że vlogi z definicji są przekazami publikowanymi w sieci. I choć celem tego artykułu nie jest rozwikływanie przynależności gatunkowych kolejnych produkcji Wellesa ${ }^{45}$, to wydaje się, że mocny pretekst do nazywania tej serii kilkunastominutowych wypowiedzi do kamery vlogami daje fakt, iż po latach znalazły przedłużenie w Internecie - medium, którego Welles wprawdzie nie znał, ale czy dla użytkowników platformy YouTube ma to jakiekolwiek znaczenie? Istotniejsze jest to, że oglądając dziś te improwizowane komentarze (przeplatane rysunkami Wellesa, co jest uwypuklone w tytule serii), można się sporo dowiedzieć na temat jego życia, poglądów politycznych, największych fascynacji czy stosunku do krytyków filmowych. Warto być może też zrewidować poglądy o jego megalomanii i arogancji. Dubliński odcinek kończy się słowami: Każdego roku uczę się, jak wiele muszę się jeszcze nauczyć.

\section{Dookoła świata i... problemów finansowych}

Po wojnie Welles zamierzał zrealizować film oparty na słynnej powieści Juliusza Verne'a $W$ osiemdziesiąt dni dookoła świata. W tym miejscu należy zaznaczyć, 
że 23 października 1938 r., a zatem dokładnie tydzień przed tym, jak wylądowali jego słynni Marsjanie, zrealizował z Mercury Theater on the Air nagranie Around the World in 80 Days na podstawie książki klasyka literatury przygodowej. Welles wcielił się w nagraniu radiowym w postać Phileasa Fogga, a partnerowali mu między innymi Ray Collins, Edgar Barrier, Eustace Wyatt, Frank Readick i Arlene Francis. Oprawę muzyczną audycji przygotował Bernard Hermann, który współpracował $\mathrm{z}$ Wellesem nie tylko w radiu - m.in. jako dyrygent orkiestry podczas historycznego słuchowiska na żywo według noweli Herberta G. Wellsa - ale jest też autorem muzyki do Obywatela Kane’a, zaś do historii przeszedł jako kompozytor najsłynniejszych filmów Alfreda Hitchcocka: Zawrót głowy (Vertigo, 1958), Pólnoc - pólnocny zachód (North by Northwest, 1959), Psychoza (Psycho, 1960).

Pierwsza wzmianka w Wellesowskich archiwach dotycząca jego zainteresowania adaptacją filmową powieści Verne'a pojawia się 19 lipca 1941 r., kiedy Reginald Armour, który współpracował przy It's All True, wysyła notatkę do RKO z pytaniem, czy Orson Welles może użyć tytułu Around the World in Eighty Days ${ }^{46}$. $\mathrm{Z}$ tym nie było problemu (nikt wcześniej nie wykupił praw do adaptacji), jednak reżyser nie mógł znaleźć pieniędzy na film, więc postanowił przygotować adaptację sceniczną książki dla Mike’a Todda, który był wówczas jednym z dyrektorów teatru na Broadwayu. Paradoksalnie, dokładnie dekadę później, Todd wyprodukował oscarowy film $W 80$ dni dookoła świata (Around the World in Eighty Days, reż. Michael Anderson, 1956) ${ }^{47}$, podczas gdy sceniczny musical Orsona Wellesa nie miał w ogóle szczęścia, bowiem słynny producent początkowo zaangażował się w zaplanowany z wielkim rozmachem projekt, ale wkrótce wycofał się i reżyser musiał wyłożyć pieniądze z własnej kieszeni. Te szybko się skończyły i kiedy Welles potrzebował 55 tysięcy dolarów ${ }^{48}$ na kostiumy, które były już przygotowane, zadzwonił do ówczesnego szefa Columbia Pictures, Harry’ego Cohna, z prośbą, aby wysłał mu czek. W zamian Welles zgodził się napisać scenariusz i wyreżyserować film dla Columbii. Tak właśnie powstała słynna Dama z Szanghaju (The Lady from Shanghai, 1947), w której Welles zagrał u boku swojej żony, Rity Hayworth ${ }^{49}$.

Sztuka muzyczna Around the World in Eighty Days miała zaś premierę na Broadwayu w Adelphi Theatre 31 maja 1946 r. po próbach w Boston Opera House. Zrealizowana z wielkim rozmachem, z zespołem liczącym blisko 150 osób, była naprawdę ekstrawagancka i spektakularna. Nie tylko z archiwalnych recenzji teatralnych i zachowanych zdjęć ze spektaklu, ale nawet sam plakat promujący widowisko pozwala się zorientować, że produkcja była rozbuchana: ogromny mechaniczny słoń, wypadek kolejowy na scenie, magiczne sztuczki, a na koniec sztuczne ognie. Gdyby to nie wystarczyło, żeby zachwycić publiczność, Welles nakręcił kilka niemych scen filmowych ${ }^{50}$, które znalazły się w tej trzygodzinnej broadwayowskiej produkcji.

Mimo świetnych recenzji kosztowna produkcja została zamknięta 3 sierpnia 1946 r. po 75 występach; letnie miesiące nie sprzyjały frekwencji, a Welles nie był w stanie dalej finansować tak ogromnego przedsięwzięcia. Kiedy biografowie nazywają tę inscenizację katastrofalna ${ }^{51}$, mają na myśli klęskę finansową; z dokumentów dostępnych w archiwach można się dowiedzieć, że reżyser stracił na tej produkcji 320 tysięcy dolarów i z powodu złych porad prawnych nie był w stanie odliczyć tych strat od podatków, a spłata długów zajęła mu lata ${ }^{52}$. 


\section{MAKGORZATA KOZUBEK}

\section{Europe First!}

Po zejściu z afisza Around the World i ukończeniu zdjęć do Damy z Szanghaju Welles zerwał na długi czas z Broadwayem i Hollywoodem. Clinton Heylin pisze aż nazbyt dosadnie i obrazowo: Ostatecznie Hollywood pożarło swego ,potencjalnego geniusza” (̇̇arcik królowej kronik towarzyskich Louelli Parson), a potem go wypluło ${ }^{53}$. W 1947 r. reżyser znalazł małą wytwórnię Republic Pictures, która zgodziła się sfinansować jego adaptację Makbeta (Mackbeth, 1948) zgodnie z budżetem klasy B, co oznaczało dla niego sporą degradację. Welles musiał nakręcić go w zaledwie dwadzieścia trzy dni ${ }^{54}$, a to nawet dla osób słabo wtajemniczonych w jego biografię brzmi dosyć nieprawdopodobnie. Film nie został dobrze przyjęty, a jego autor od dłuższego już czasu był w kiepskiej kondycji, o czym świadczy skrajnie pesymistyczny ton korespondencji z tego okresu. Zarówno w życiu artystycznym, jak i osobistym (rozwód z Ritą Hayworth) ${ }^{55}$ daleko odszedł od raju. Autoportrety rysowane przez niego w tym czasie są opatrzone podpisem: Kolejny autoportret litości dla siebie ${ }^{56}$.

Złota Palma w Cannes za Otella (The Tragedy of Othello: The Moor of Venice, 1951) pomogła mu nieco podnieść się z impasu artystycznego, a występy w Trzecim człowieku (The Third Man, reż. Carol Reed, 1949), Księciu lisów (Prince of Foxes, reż. Henry King, 1949) i Czarnej róży (The Black Rose, reż. Henry Hathaway, 1950) podreperowały stan jego finansów. Natomiast pogodę ducha odzyskał dopiero, realizując produkcję telewizyjną Around The World with Orson Welles. Serię trawelogów emitował nowo powstały komercyjny kanał ITV (Independent Television) ${ }^{57}$ od października do grudnia 1955 r., a po sześćdziesięciu latach wydał ją w odrestaurowanej wersji na dvd British Film Institute.

Around The World with Orson Welles nawiązuje do przywoływanej już serii Orson Welles'Sketchbook realizowanej niemal w tym samym czasie dla BBC. Najlepszym przykładem są epizody poświęcone walkom byków: „vlog” Bullfighting, wyemitowany na początku lipca 1955 r., został rozwinięty w ostatniej części eseju filmowego z podróży pod tytułem Spain - The Bullfight, wyświetlonego przez ITV pięć miesięcy później. Mimo różnic wynikających z formatu obu produkcjom Welles nadał swój niepowtarzalny styl. Jednak to dzienniki z podróży odsłaniają najwyraźniej - obok poczucia humoru i przenikliwej inteligencji reżysera - jego wrażliwość społeczną i umiejętność nawiązywania swobodnych kontaktów z rozmówcami, niezależnie od tego, czy są nimi kilkuletnie baskijskie dzieci, czy osiemdziesięcioparoletni angielscy weterani wojenni.

Tradycja relacjonowania podróży ma oczywiście odległą tradycję - ruchomymi pocztówkami z dalekich wypraw były już filmy operatorów braci Lumière, ale warto zwrócić uwagę na formalne rozwiązania trawelogów Wellesa. Seria Around The World ... z jednej strony bliska jest założeniom nurtu dokumentalnego cinéma-vérité, który rozwinie się we Francji w latach 60 . XX w., z drugiej reżyser chętnie sięga do kojarzonych z nim rozwiązań fabularnych. Przeprowadzając wywiady z kolejnymi rozmówcami, przywodzi momentami na myśl postać reportera Thompsona z Obywatela Kane'a, który jest filmowany zawsze od tyłu, nie dając szansy widzowi na przyjrzenie się jego twarzy. Welles nie byłby oczywiście sobą, gdyby nie pokazywał się od czasu do czasu na ekranie, choć - kolejny ulubiony chwyt - na pojawienie się go w pełnej krasie zwykle musimy trochę poczekać. Nie są to spektakularne „wej- 


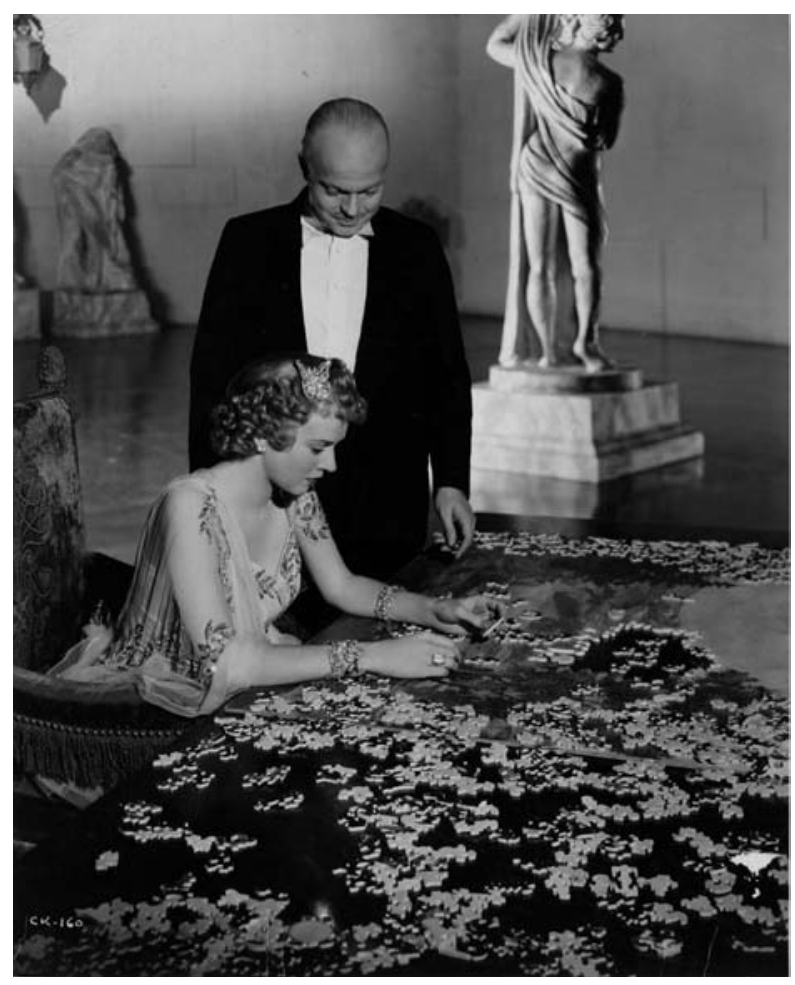

Obywatel Kane, reż. Orson Welles (1941)

ścia”, jak w Obywatelu Kanie w scenie rozgrywającej się w siedzibie „Inquirera” lub w Procesie, kiedy postać grana przez Wellesa wyłania się spod kołdry w kłębach dymu z cygara w połowie filmu, czy w Trzecim człowieku, w którym na jego pojawienie się czekamy ponad godzinę. Ale już chociażby wspomniany madrycki odcinek przypomina takie rozwiązania: krytyk Kenneth Tynan i jego ówczesna żona, amerykańska pisarka Elaine Dundy, w przeciąganym w nieskończoność ujęciu ustanawiającym recytują napisane przez reżysera informacje o walkach byków i zapowiadają, że wkrótce dołączy do nich sam Orson Welles.

Można by nawet kąśliwie nazwać te dokumentalne relacje z europejskich miejsc swoiście narcystycznymi działaniami autopromocyjnymi, zwłaszcza kiedy weźmiemy pod uwagę, że wypełniają one jego dosyć ubogą filmografię dekady lat 50., w której zrealizował jedynie trzy filmy pełnometrażowe. A jednak potencjalną ironię rozbraja empatia Wellesa i jego ogromne zainteresowanie historiami rozmówców, wobec których jest niezwykle uprzejmy, a momentami wręcz czuły.

Pod tym względem wyróżniają się dwa pierwsze odcinki serii, które dotyczą historii i kultury Basków: The Basque Countries i La Pelote Basque ${ }^{58}$ oraz epizod nakręcony w Londynie: The Queen's Pensioners, w którym Welles z powagą i życzliwością przysłuchuje się wdowom i weteranom wojennym - to oni są na pierwszym planie, a Welles jak mantrę powtarza wygłoszoną przez nich lekcję na temat konieczności przeżycia zmierzchu życia w poczuciu niezależności. W drugim z baskijskich odcinków kamera Wellesa nie tylko skupia się na dzieciach grających 
w pelotę, choć sport ten uprawiają tam wszyscy włącznie z księdzem miotającym się w niewygodnej sutannie, ale przewodnikiem w opowieści staje się jedenastoletni Chris, z którym Welles dzieli się narracją. Reżyser jest pogodny, wygląda na szczęśliwego i odmłodzonego zarówno przez temat, jak i obecność rezolutnych dzieci. Kończy jednak dosyć sentymentalnie: na tle nocnego nieba oświetlonego fajerwerkami mówi, że baskijskie zakończenia są inne niż amerykańskie w stylu „....i żyli długo i szczęśliwie”. Kończą się mianowicie zdaniem ... i jeśli żyli dobrze, umrą dobrze.

Jednym z najbardziej błyskotliwych i nieszablonowych odcinków jest Saint-Germain-des-Prés zrealizowany w Paryżu. Po pierwsze, Welles decyduje się na ciekawe rozwiązania fabularne, rodem niemalże z Obywatela Kane'a i ze Sznura (Rope, 1948) Alfreda Hitchcocka. Po drugie, nie kusi się na spotkania i rozmowy z dobrze mu znaną paryską elitą artystyczną, które byłyby filmowymi samograjami. Jean Cocteau, Juliette Gréco, Simone de Beauvoir, którzy mieszkali w tytułowej dzielnicy w latach 50., są uchwyceni jedynie w krótkich migawkach - dosłownie przemykają przed kamerą, a Eddie Constantine uśmiecha się tylko do widza znad kawiarnianego stolika. Welles decyduje się za to na długi wywiad z ekscentrycznym, nieco zapomnianym amerykańskim artystą Raymondem Duncanem (bratem znanej tancerki, Isadory Duncan). Jest to piękny, autentyczny portret rzeźbiarza, malarza, rzemieślnika i filozofa, który w uszytych przez siebie ubraniach przypomina nieco Sokratesa. Welles jest tak zafascynowany Duncanem, że czasem zapomina filmować siebie podczas wywiadu. Spotkanie to przełamuje granice doświadczenia turystycznego i pocztówkowego ujęcia Paryża. Wellesa nie interesują turystyczne atrakcje, upowszednianie znanych widoków; w filmie ani razu nie pojawia się najbardziej znany symbol Paryża, mimo że Welles był zafascynowany architekturą wieży Eiffla, na co wskazują jego liczne rysunki tej budowli.

Paryski odcinek otwiera statyczne zbliżenie na obiektyw aparatu filmowego chwyt znany już z innych odcinków Around the World... jednak akcja od razu nabiera tempa: szybka jazda kamery przenosi nas pod budynek europejskiej siedziby „New York Herald Tribune”, najeżdżając - jak w pierwszej scenie Sznura - na same okna. Po tym efektownym travellingu następuje ostre cięcie (znów jak u mistrza suspensu), tym razem jednak widza nie czeka ,trzęsienie ziemi” i morderstwo w pierwszej minucie filmu, ale miła niespodzianka: w dziennikarzu wyrwanym przez dźwięk telefonu z lektury gazety rozpoznajemy Arta Buchwalda. Popularny satyryk polityczny, który po wojnie był korespondentem znanych pism amerykańskich i zdawał Amerykanom relacje między innymi z paryskiego życia kulturalnego, dobrze wczuł się w rolę zaproponowaną przez Wellesa; z zapałem zaczyna pisać na maszynie felieton Paryż po zmroku, rozpoczynając go od słów: Orson Welles jest na Saint-Germain-des-Prés. Wielkie zbliżenie na maszynę do pisania, dokładnie takie jak w Obywatelu Kane, pokazuje wyraźnie, że reżyser bawi się formą filmową, miesza dokument z fikcją, co najpiękniej zaowocuje później w F jak fatszerstwo (Vérités et mensonges, 1973).

Art Buchwald prosi sekretarkę o teczkę z materiałami o Wellesie, żeby wybrać zdjęcie najlepiej ilustrujące felieton. Po krótkim przeglądzie wybór pada na fotografię, na której Welles nalewa sobie wino z wielkiej beczki ${ }^{59}$. Pomost dźwiękowy przenosi nas do jednej z głośnych paryskich kawiarenek, do której wchodzi zadowolony reżyser. Muzyka i sposób, w jaki są filmowani tańczący ludzie, polskiemu 
kinofilowi od razu skojarzą się z dynamiczną sekwencją z dokumentu otwierającego „czarną serię" Uwaga chuligani! w reżyserii Jerzego Hoffmanna i Edwarda Skórzewskiego, zrealizowanego w tym samym roku, co Around the World... (1955), albo ze znaną etiudą Romana Polańskiego Rozbijemy zabawę (1957). Już wkrótce w Paryżu zaczną powstawać filmy twórców nowofalowych, którzy zawsze skupiali uwagę na czasie teraźniejszym, a nawet na chwili bieżacej, która tak bardzo starali się uchwycić kamera (...) postaciach, które nie tylko żyly w Paryżu, lecz żyly nim ${ }^{60}$. To wszystko udało się zawrzeć Wellesowi w dwóch pierwszych minutach filmu, co powinno stanowić wystarczającą zachętę do obejrzenia całego odcinka.

Po poruszających materiałach z Londynu i nieszablonowych ujęciach Paryża moglibyśmy oczekiwać, że kolejny odcinek, nakręcony w Madrycie The Bullfight, będzie jeszcze lepszy - nie tylko corrida była jedną z największych fascynacji Wellesa ${ }^{61}$, ale miał ogromną słabość do Hiszpanii w ogóle. Oja Kodar opowiadała, jak podczas montowania Drugiej strony wiatru zaczęła pisać scenariusz pod tytułem Crazy Weather, a historia tego (niezrealizowanego) filmu miała się rozgrywać w Hiszpanii. Welles natychmiast zainteresował się projektem i poprosił ją o możliwość współpracy w tworzeniu scenopisu: Kiedy tylko coś miało mieć wspólnego z Hiszpania, od razu chcial być w to jakoś zaangażowany! A więc wspólnie napisaliśmy ten scenariusz. I udało mu się wprowadzić temat corridy, choć ja sama nie cierpię walk byków ${ }^{62}$. Tymczasem w epizodzie madryckim Welles powtarza wprost do kamery klasyczną meksykańską historię o przyjaźni małego chłopca Juana z bykiem Bonito ${ }^{63}$, którą przedstawił już w serii zrealizowanej dla BBC cztery miesiące wcześniej (Orson Welles’ Sketchbook. Bullfighting).

Madryckiemu odcinkowi brakuje ekspresji. Pomimo kontrowersyjnej i ekscytującej tematyki większość materiału stanowią statyczne, długie ujęcia, a we fragmentach z walkami byków aż się prosi o dynamiczny materiał filmowy. Kamera Wellesa jest uziemiona na trybunach, z których macha on od czasu do czasu do małżeństwa Tynnanów otwierających odcinek. Szkoda, że tak jak w początkowych i końcowych ujęciach z Saint-Germain-des-Prés, czy w drugim baskijskim odcinku, reżyser nie jest tak pomysłowy, że nie rozwija aktywnego, wirującego stylu kamery i szybkiego montażu, którym tak umiejętnie operował w tym czasie w fabule, czego przykładem może być Pan Arkadin / Poufny raport (Mr. Arkadin, 1955). Największym mankamentem tego epizodu jest jednak montowanie ujęć z madryckiej areny z przeciwujęciami naprędce dokręconymi najwyraźniej już w studiu. Odnosimy wrażenie, jakby reżyser po prostu wykorzystywał fragmenty z wcześniejszych szkicowników do wypełnienia półgodzinnego odcinka dla BBC. Fani Wellesa mogą oczywiście uznać, że był to zabieg zamierzony, ,„przezroczyste oszustwo"; ostatecznie arcydzieło $F$ jak fałszerstwo zrodziło się właśnie z takiego ostentacyjnego manipulowania obrazem.

Natomiast niewątpliwie oryginalnym pomysłem było zrealizowanie jednego z odcinków w Wiedniu i opatrzenie go podtytułem The Third Man Returns to Vienna. Welles jako aktor grający Harry’ego Lime’a, czyli tytułowego Trzeciego człowieka w filmie Carola Reeda, wraca do miejsc, w których był kręcony ten czarny kryminał i oprowadza po nich widza. Spotykamy między innymi Antona Karasa grającego na cytrze muzyczny motyw przewodni filmu, który rozpozna chyba każdy kinofil. Mimo że persona Wellesa jest uwypuklona w tytule odcinka, nie rozwodzi się on zbytnio nad swoim aktorskim sukcesem sprzed lat. Welles był 
narcystyczny, ale nie tak bardzo, jak się zwykło o nim myśleć, mówić i pisać. Mając czterdzieści lat, a zatem w roku kręcenia Around the World with Orson Welles, powiedział: Prawdziwemu buntownikowi musi brakować tych ostatnich dziesięciu procent ambicji - musi być bardziej zainteresowany tym, co robi niż tym, kim jest. Gdy ma się dwadzieścia lat z niewielkim okładem, tkwi w nas pewien rodzaj arogancji i egoizmu, które z czasem się ulatniają, lecz miłość do tego, co się robi, nie gaśnie ${ }^{64}$.

Nie bez powodu kończymy wędrówkę szlakiem Orsona Wellesa w Wiedniu. Przez wiele lat uważano, że wiedeński odcinek zaginął. Dopiero w czerwcu $2011 \mathrm{r}$. został odnaleziony przez Raya Langstone'a w archiwach Centrum Badań nad Filmem i Teatrem Towarzystwa Historycznego Wisconsin w Madison i uzupełnił cykl. Ile jeszcze takich Wellesowskich filmowych odkryć przed nami? To już temat na zupełnie inną podróż...

Matgorzata KozUBeK

${ }^{1}$ M. Przylipiak, Polska recepcja twórczości Orsona Wellesa, w: Orson Welles. Twórczość Recepcja-Dziedzictwo, red. P. Biliński, B. Filip, K. Kornacki, M. Maciejewska, Wydawnictwo Uniwersytetu Gdańskiego, Gdańsk 2016, s. 33.

${ }^{2}$ Tamże. Przywołany tu pokonferencyjny tom (podobnie notabene jak drugi numer „Ekranów” z 2015 roku - również inspirowany okrągłymi urodzinami Orsona Wellesa i w znacznej mierze jemu poświęcony), proponuje ważną zmianę w pisaniu o Wellesie, odcinając się od wyświechtanych frazesów na jego temat czy kolejnych analiz formalnych Obywatela Kane'a. Na szczególną uwagę zasługuje artykuł Rafała Syski poświęcony producentom wytwórni RKO, w którym autor szczegółowo analizuje strategie produkcyjne i specyfikę pracy tego studia filmowego. Wcześniej na polskim gruncie ograniczano się bowiem jedynie do stwierdzeń typu: Welles na poczatku kariery otrzymał kontrakt, o jakim inni mogli tylko marzyć. Zob. R. Syska, Niewidoczni bohaterowie pierwszego planu. RKO a Orson Welles, tamże, s. 59-71.

${ }^{3}$ P. Bagh, Some Minor Keys to Orson Welles, w: The Unknown Orson Welles, red. S. Drössler, Filmmuseum München \& Belleville Verlag, München 2004, s. 6.

${ }^{4}$ C. Heylin, Pod prąd. Orson Welles kontra Hollywood, tłum. J. Kozłowski, Wydawnictwo Książkowe Twój Styl, Warszawa 2007, s. 439.

${ }^{5}$ Tamże.

${ }^{6}$ Największymi zasobami archiwalnymi dysponują dwie biblioteki w Stanach Zjednoczonych: Lilly Library przy Uniwersytecie Indiana w Bloomington oraz biblioteka University of Michigan w Ann Arbor. Pierwsza z nich posiada również zbiory Arnolda Weissbergera (prawnika Wellesa) oraz George'a Fanto (jego operatora). W kwietniu 2017 r. druga z wymienionych instytucji wzbogaciła się między innymi o liczne materiały przekazane przez córkę reżysera, Beatrice Welles. Okazałą kolekcją oryginalnych dokumentów dysponują również historyczne archiwa Narodowego Muzeum Kina w Turynie (obejmują lata 1960-1976), które pomagają w znacznej mierze zrozumieć powody nieukończenia wielu projektów filmowych Wellesa z okresu jego europejskiej twórczości. Wprawdzie materiały były dostępne dla czytelników już w 1998 r., ale Bibliomediateka Mario Gromo zakupiła je na aukcji bez żadnego rozgłosu. Archiwa te zostały ,odkryte” przez włoskich badaczy Massimiliano Studera i Alessandro Aniballego dopiero w $2018 \mathrm{r}$.

${ }^{7}$ Procent zdigitalizowanych materiałów jest na razie znikomy. W pierwszej kolejności zostały opracowane materiały związane z Obywatelem Kane'em. W kwietniu tego roku Lilly Library otrzymała jednak ponaddziesięciomilionowy grant, a zatem należy się spodziewać, że materiałów tych będzie przybywać. Prawdziwą skarbnicą wiedzy na temat Wellesa jest strona http://www.wellesnet.com, istniejąca od 2001 r., na której również można znaleźć część trudno dostępnych wcześniej informacji.

${ }^{8}$ Zob. M. Kozubek, Ostatnia strona ,Obywatela Kane'a”, „Prace Kulturoznawcze” 2018, nr 3, s. $13-26$.

${ }^{9}$ J. Skwara, Orson Welles, Wydawnictwa Artystyczne i Filmowe, Warszawa 1967, s. 9. 


\section{DOOKOŁA ŚWIATA Z ORSONEM WELLESEM}

${ }^{10}$ S. Callow, Orson Welles: Hello Americans, Vintage, London 2007, s. 63.

${ }^{11}$ D. Thomson, Rosebud. The Story of Orson Welles, Abacus, London 1996, s. 9.

${ }^{12}$ Nawiązuję tu do tytułu wyczerpującej monografii autorstwa C. Benamou, It's All True: Orson Welles's Pan-American Odyssey, University of California Press, Oakland 2007.

${ }^{13}$ C. Heylin, dz. cyt., s. 163.

${ }^{14}$ Tamże.

${ }^{15}$ Welles i Wilson na domiar złego dowiedzieli się o tym z gazet, zob. C. Heylin, dz. cyt., s. 164.

${ }^{16}$ Ch. Berg, It's All True, w: The Encyclopedia of Orson Welles. From „The Hearts of Age” to „F for Fake”, red. Ch. Berg, T. Erskine, Facts on File, New York 2003, s. 173.

17 Jedyna przethumaczona na język polski biografia Wellesa, cytowana już książka Clintona Heylina Pod prad. Orson Welles kontra Hollywood, w całości skupia się na tym aspekcie. Welles również poza Hollywood niejednokrotnie nie mógł dojść do porozumienia z producentami. Jednym z najciekawszych, choć zarazem chyba najbardziej kuriozalnym przykładem jest ten związany z telewizyjną Nieśmiertelna historia (Histoire immortelle, 1968), która miała zapoczątkować serię trzech adaptacji prozy Isaka Dinesena (właśc. Karen Blixen); pozostałe - The Heroine i Full Moon, nie zostały nigdy ukończone. Do drugiej części - The Heroine wszystko, włącznie z kostiumami, było przygotowane i ekipa udała się w 1969 r. do Budapesztu na zaproszenie węgierskiego producenta. Film kręcono tylko przez jeden dzień, ponieważ wieczorem Welles zorientował się, że całą produkcję będzie musiał sfinansować sam, gdyż producent nie ma w ogóle pieniędzy. Z zaplanowanej serii powstała zatem tylko Nieśmiertelna historia i kilka zachowanych w archiwach zdjęć z jednego dnia zdjęciowego do The Heroine. Zob. S. Drössler, Oja as a Gift - Interview with Oja Kodar, w: The Unknown Orson Welles, dz. cyt., s. 42-43.

${ }^{18}$ Godnym polecenia opracowaniem poświęconym związkom Wellesa z Hiszpanią jest rozdział In the Land of Don Quixote w książce Matthew A. Geara At the End of the Street in the Shadow. Orson Welles and the City, Wallflower Press, London and New York 2016, s. 584-644.

${ }^{19}$ Zob. m. in. R. Syska, „Don Kichot” Orsona Wellesa: niedokończona podróż na Księżyc, w: Od Cervantesa do Pereza-Reverte'a. Adaptacje literatury hiszpańskiej i iberoamerykańskiej, red. A. Helman, K. Żyto, Fundacja Kino, Warszawa 2011, s. 18-33 oraz M. Bar- baruk, Don Kichote niewierny: kontrkulturowość niespetnienia, „Prace Kulturoznawcze”, dz. cyt., s. 27-39.

${ }^{20}$ Zob. C. Benamou, dz. cyt. oraz: A. Anile, Orson Welles in Italy, Indiana University Press, Bloomington \& Indianapolis, 2013 i D. Kovačić, D. Rafaelić, Orson Welles u Hvaru/Orson Welles in Hvar, Zagreb 2018.

${ }^{21}$ Welles zakupił prawa do ekranizacji Małego Księcia 15 czerwca 1943 r. Oryginalny scenariusz z rysunkami Wellesa liczy 76 stron i znajduje się w zbiorach Lilly Library.

${ }^{22}$ André Bazin, jako jeden z pierwszych krytyków zwrócił uwagę na ważny motyw nostalgii za utraconym rajem w twórczości Wellesa. Zob. tenże, Orson Welles. A Critical View, Harper \& Row Publishers, New York - Hagerstown - San Francisco - London 1978, s. 65.

${ }^{23} \mathrm{Na}$ ten temat zob. D. Thomson, dz. cyt. s. 6-8.

${ }^{24}$ Zwraca na to uwagę, nie bez ironii, M. Przylipiak, zob. tenże, dz. cyt., s. 26-27.

${ }^{25}$ P. McGilligan, Young Orson. The Years of Luck and Genius on the Path to ,Citizen Kane”, Harper Collins Publishers, New York 2015, s. 5.

${ }^{26} \mathrm{~W}$ Todd School jedenastoletni wówczas Welles poznał Rogera Hilla, entuzjastę radia i teatru, który miał wpływ na zainteresowania artystyczne przyszłego reżysera. To tam po raz pierwszy, w ramach kółka dramatycznego, opracował spektakl, w którym wykorzystał motywy kilku sztuk Szekspira. Welles, jak wiadomo, często tak postępował w późniejszych latach, również przy filmie Falstaff (Campanadas a medianoche, reż. Orson Welles, 1965).

${ }^{27}$ J. Skwara, dz. cyt., s. 9.

${ }^{28}$ Zob. Orson Welles: Interviews, red. M. W. Estrin, University Press of Mississippi, Jackson 2002, s. 131. Por. D. Thomson, dz. cyt., s. 10. ${ }^{29}$ Tamże, s. 10-11.

${ }^{30} \mathrm{O}$. Welles, P. Bogdanovich, This is Orson Welles, red. J. Rosenbaum, Harper Collins Publishers, New York 1992.

${ }^{31}$ Tamże, s. 93.

${ }^{32}$ Tamże.

${ }^{33}$ Nazwa karczmy nie jest przypadkowa, Welles w pierwszym rozdziale nigdy nieukończonej autobiografii wspomina, że restauracja w hoteliku ojca specjalizowała się między innymi w potrawach z dziczyzny. Zob.: A Marry Christmas from Orson Welles, http://www.wellesnet.com/a-merry-christmas-from-orsonwelles/ (dostęp: 25.08.2019).

${ }^{34}$ Film był realizowany w Hiszpanii. Do pracy nad scenografią Welles zatrudnił Mariano Erdoizę, ale pracował on według szczegółowych rysunków przygotowanych przez reżysera. 
${ }^{35}$ A. Helman, Orsona Wellesa portret rodziny we wnętrzu - „Wspaniałość Ambersonów”, w: Arcydzieła klasycznego kina amerykańskiego, red. Ł. A. Plesnar, R. Syska, Stowarzyszenie Przyjaciół Czasopisma o Tematyce Audiowizualnej EKRANy, Kraków 2013, s. 167.

${ }^{36}$ A Marry Christmas from Orson Welles, dz. cyt.

${ }^{37}$ „Vogue”, December/January, red. O. Welles, Paris, 1982.

${ }^{38}$ A Marry Christmas from Orson Welles, dz. cyt.

${ }^{39}$ D. Boorstin, The Image, New York 1967, s. 85. Cyt. za J. Culler, Semiotyka turyzmu, thum. H. Baczewska, „Panoptikum” 2009, nr 8, s. 13-14.

${ }^{40}$ S. Callow, Orson Welles: The Road to Xanadu, Vintage, London 1996, s. 77.

${ }^{41}$ Tamże.

${ }^{42}$ Tamże, s. 78. Na marginesie można wspomnieć, że jednym z ulubionych filmów Wellesa był Nanuk z Pótnocy (Nanook of the North, reż. Robert Flaherty, 1922), zob. C. Heylin, dz. cyt., s. 29.

${ }^{43}$ S. Callow, Orson Welles: The Road to Xanadu, dz. cyt. s. 79.

44 Tamże, s. 87.

${ }^{45} \mathrm{Na}$ temat eksperymentowania Wellesa $\mathrm{z}$ filmem dokumentalnym zob. P. Biliński, Orsona Wellesa zabawy w dokument(alny esej), w: Orson Welles. Twórczość - Recepcja-Dziedzictwo, dz. cyt., s. 96-108.

${ }^{46}$ Zob. R. Armour to RKO, 19 July 1941, Orson Welles Manuscripts, Lilly Library.

47 Twórcy wykorzystali wiele pomysłów inscenizacyjnych Wellesa, który tym bardziej miał za złe Toddowi, że ten nie zaangażował go w żaden sposób do filmu.

${ }^{48}$ Zob. C. Heylin, dz. cyt., s. 253. Por. „Around the World musical" opened on Broadway 70 years ago, http://www.wellesnet.com/aroundthe-world-musical-opened-on-broadway-70years-ago/ (dostęp 25.08.2019).

${ }^{49}$ Więcej na temat okoliczności związanych z obsadzeniem Rity Hayworth w tytułowej roli zob. M. Kozubek, Kobiety Wellesa w: Orson Welles. Twórczość - Recepcja-Dziedzictwo, dz. cyt. s. 140 .

${ }^{50}$ Podobnie jak zrobił w przypadku filmu Too Much Johnson (1938), który pierwotnie był wyświetlany podczas jednego z przedstawień teatralnych i był rodzajem prologu potrzebnego, by zapoznać publiczność z tym, co się działo przed rozpoczęciem spektaklu; w Around The World... Welles nakręcił z kolei serię niemych filmów, żeby naświetlić niektóre $\mathrm{z}$ bardziej egzotycznych miejsc w legendarnej podróży Phileasa Fogga.

${ }^{51}$ C. Heylin, dz. cyt., s. 307.

${ }^{52}$ Weissberger Manuscriptes, Lilly Library, por. „Around the World musical” opened on Broadway 70 years ago, dz. cyt.

${ }^{53}$ C. Heylin, dz. cyt., s. 8.

${ }^{54}$ Więcej na ten temat zob. O. Welles, P. Bogdanovich, dz. cyt. s. 205-219.

55 Zob. M. Kozubek, Kobiety Wellesa, dz. cyt. s. 138-139.

${ }^{56}$ Hayworth Manuscriptes, Lilly Library.

${ }^{57}$ Kanał wystartował 22 września $1955 \mathrm{r}$.

${ }^{58} \mathrm{Na}$ temat tych dwóch odcinków zob. M. A. Gear, dz. cyt., s. 591-597.

${ }^{59}$ Zdjęcie to zostało wykonane w Monachium, oryginał znajduje się w Filmmuseum München.

${ }^{60}$ E. Mazierska, L. Rascaroli, Turyści, podróżnicy $i$ wspótczesne kino transnarodowe, ,Panoptikum" 2009, nr 15, s. 135-136.

${ }^{61} \mathrm{Na}$ temat swojej fascynacji walkami byków Welles opowiedział m. in. Peterowi Bogdanovichowi, zob. O. Welles, P. Bogdanovich, dz. cyt., s. 43-44.

${ }^{62}$ S. Drössler, dz. cyt., s. 43. Kodar zaczęła pisać scenariusz ok. 1973 r. Co ciekawe, historia opowiedziana w scenariuszu, który jest dostępny $\mathrm{w}$ archiwum $\mathrm{w}$ Turynie, przypomina znaną nam dobrze z Noża $w$ wodzie (reż. R. Polański, 1961); zamożna para jedzie na walkę byków i po drodze zabiera młodego mężczyznę.

${ }^{63}$ Historię tę zawarł wiele lat wcześniej również w scenariuszu It's All True (1941-1942). Notabene jest ona oparta na opowiadaniu Roberta Flaherty'ego Mój przyjaciel Bonito o chłopcu, który wychowuje się na farmie, zaprzyjaźnia z młodym zwierzęciem później wysłanym na arenę, ale dzięki niezwykłej odwadze chłopca uratowanym od śmierci.

${ }^{64}$ C. Heylin, dz. cyt., s. 291. 